\title{
ANALISIS FAKTOR-FAKTOR YANG MEMPENGARUHI TARIF PAJAK EFEKTIF
}

\author{
Yanuar Nanok Soenarno \\ Universitas Atmajaya Jakarta \\ yanuar.nanok@atmajaya.ac.id
}

\begin{abstract}
This research wanted to see whether financial factors such as profitability, leverage, liquidity, market share and cash flow affects the company in paying taxes. This study uses all non-financial companies listed on the Indonesia Stock Exchange listing in 2012. From this research resulted that profitability, leverage and liquidity factors affect the level of corporate tax payments. However, shareholder and cash flow factors whose expectations are influential, have no effect. Tax payment strategies that still rely on tax shield to reduce tax payments, making many companies more borrowed to get the funds.
\end{abstract}

Keywords: efective tax rate, profitability, leverage, liquidity, cash flow, Indonesia stock exchange.

\begin{abstract}
ABSTRAK : Penilitian ini ingin melihat apakah faktor-faktor keuangan seperti profitabilitas, leverage, likuiditas, pasar saham dan cash flow mempengaruhi perusahaan dalam membayar pajak. Penelitian ini menggunakan seluruh perusahaan non keuangan yang ada di Bursa efek Indonesia yang listing pada tahun 2012. Dari penelitian ini dihasilkan bahwa faktor profitabilitas, leverage dan likuiditas berpengaruh terhadap tingkat pembayaran pajak perusahaan. Namun demikian faktor pemegang saham dan cash flow yang harapannya berpengaruh, tidak berpengaruh. Strategi pembayaran pajak yang masih mengandalkan tax shield untuk mengurangi pembayaran pajak, membuat banyak perusahaan lebih banyak meminjam untuk mendapatkan dana.
\end{abstract}

Kata Kunci: efective tax rate, profitability, leverage, liquidity, cash flow, Indonesia stock exchange.

\section{PENDAHULUAN}

\section{Latar belakang}

Sebuah laporan Riset yang berjudul Global Effective Tax Rates (effective tax rate) dipublikasikan pada 14 April 2011 dalam Business Roundtable, menyebutkan bahwa tarif pajak efektif di Indonesia termahal keempat di dunia setelah Jepang, Maroko, dan Italia.Riset dilakukan oleh Business Roundtable dan PricewaterhouseCoopers UP (PwC) (Investor Daily ,2011).Dalam risetnya tersebut $\mathrm{PwC}$ meneliti 1.820 perusahaan dunia yang masuk dalam daftar Forbes 2000 . Sebanyak 484 perusahaan di antaranya bermarkas di Amerika Serikat dan 1336 sisanya bermarkas di 58 negara, dengan rentang penelitian 2006-2009.

Tarif pajak efektif (effective tax rate) didefinisikan sebagai akumulasi total pungutan pajak (total income taxes) dibagi pendapatan sebelum pajak perusahaan. Total pungutan pajak dihitung PwC dari akumulasi pungutan-pungutan pajak mulai dari tingkat pemerintahan lokal, provinsi, nasional, hingga oleh pemerintahan asing asal perusahaan tersebut selama setahun.

Dari penelitian tersebut rasio pajak efektif Indonesia adalah sebesar 28,1\% atau berada di urutan keempat, setelah Jepang $(38,8 \%)$, Maroko $(33,9 \%)$, dan Italia $(29,1 \%)$. Jika dibandingkan dengan negara- 
negara Asean, posisi Indonesia tersebut sangat buruk. Sebagai contoh, Thailand berada di urutan ke-16 dengan skor $24,6 \%$, Malaysia urutan 23 (22,8\%), Singapura urutan $46(16,3 \%)$ dari 59 negara. India berada di posisi $14(25,1 \%)$ dan Tiongkok posisi $28(21,5 \%)$. Amerika Serikat di urutan keenam $(27,7 \%)$.

Tarif pajak perusahaan multinasional di Indonesia juga jauh lebih tinggi dibandingkan koleganya yang berkantor di negara-negara non- OECD. Selisihnya sangat besar, yakni $28,1 \%$ berbanding $16,5 \%$. Hal yang sama juga terjadi jika dibandingkan dengan kawasan Uni Eropa (18 negara) yang tarifnya sebesar $21,9 \%$ atau 58 negara di luar AS $(19,5 \%)$ dan 28 negara OECD di luar AS $(22,6 \%)$.

\section{Tujuan Riset}

Dengan latar belakang yang telah dipaparkan di atas, penulis tertarik untuk melakukan penelitian mengenai tarif pajak efektif melalui perusahaan-perusahaan yang listed di Bursa Efek Indonesia kemudian menguji antar factor-faktor yang mungkin mempengaruhi tarif pajak efektif, seperti Profitabilitas, Leverage, Likuiditas, Investment Indicators dan Cash Flow Indicators.

\section{Urgensi Penelitian}

Penelitian yang mengkaji tentang tarif pajak efektif masih sangat jarang di Indonesia. Hal ini mungkin disebabkan kesalahan banyak pihak yang menganggap bahwa tarif pajak efektif sama dengan tarif pajak yang ditetapkan oleh pemerintah. Namun tidak demikian hasilnya, tarif pajak efektif dipengaruhi oleh dua hal, yaitu peraturan pemerintah yang mempengaruhi besarnya tarif pajak efektif suatu industri dan strategi pajak perusahaan (perencanaan pajak). Menanggapi hasil penelitian tersebut, pengamat perpajakan Darussalam membenarkan bahwa tarif pajak yang ditanggung perusahaan multinasional di Indonesia sangat tinggi.Dia memaparkan, selama ini keberadaan pajak-pajak daerah sulit dipantau. Apalagi selama ini tidak pernah ada penelitian berapa banyak jenis pajak yang dibayarkan perusahaan yang beroperasi di Indonesia, termasuk total tarif pajaknya. Pemerintah hanya tahu perusahaan membayar pajak bumi bangunan, pajak penghasilan, pajak pertambahan nilai, dan lain sebagainya.Tapi memang belum ada penelitian komprehensif soal pungutan pajak di Indonesia.Pemerintah juga belum pernah meneliti berapa besar tarif pajak yang harus ditanggung perorangan maupun perusahaan yang beroperasi di Indonesia.Oleh karena itu penelitian PwC itu bagus untuk ditelaah lebih lanjut dan perlu dipikirkan secara komprehensif.Darussalam juga mengatakan sebetulnya tarif pajak yang tinggi tidak masalah asalkan manfaat dari pajak bisa dirasakan, seperti yang berlaku di negaranegara Skandinavia. Oleh karena itu, dia mendesak agar pemerintah meneliti berapa total tarif pajak yang harus dibayarkan suatu perusahaan yang beroperasi di Indonesia.

Perbedaan pajak yang terlalu jauh dengan negara lain membuat perlunya dipertimbangkan karena dapat membuat sejumlah perusahaan asing enggan membuka perusahaan di Indonesia. Untuk itu, Indonesia perlu melakukan survei yang ditujukan kepada perusahaan asing yang beroperasi di Indonesia terkait pajak yang berlaku di Indonesia.

\section{TINJAUAN LITERATUR}

Topik mengenai jumlah tarif pajak efektif yang dibayar perusahaan telah menjadi pembicaraan di Amerika di tahun 1990 an (Kern and Morris, 1992 ; Kim and Limpaphayom, 1998 ; Porcano, 1986 ; Salamon and Siegfried, 1977 ; Wilkie and Limberg, 1990 ; Zimmerman, 1983). Yang menarik disini adalah apakah penelitian tarif pajak efektif di Amerika ini dapat digeneralisasikan ke Negara-negara di timur atau di Asia Tenggara, terutama di Indonesia. Faktor-faktor apa saja yang menjelaskan atau mempengaruhi tarif pajak efektif untuk perusahaan yang bukan perusahaan Amerika.

Tarif pajak efektif sering digunakan untuk mengukur keberhasilan suatu perusahaan (atau kegagalan) dalam pengendalian biaya, effective tax planning, dan hasil pengelolaan keuangan secara keseluruhan. Tarif pajak efektif juga merupakan konsep laba 
akuntansi yang mempengaruhi laporan arus kas perusahaan dan laporan laba (rugi).Dalam menentukan besaran tarif pajak efektif kebanyakan perusahaan melakukan rekonsiliasi terlebih dahulu. Terdapat 2 pendekatan untuk menghitung tarif pajak efektif : pertama adalah pendekatan tradisionaldan yang kedua adalah pendekatan dari analisa strategi tarif pajak (Roesler, Nishita; Getz, CJ, 2004).

Pendekatan tradisional menggunakan rekonsiliasi pajak, rekonsiliasi pajak ini digunakan untuk menentukan komponen tarif pajak efektif.Rekonsiliasi ini menghitung perbedaan antara beban pajak penghasilan menurut laporan akuntansi dan beban pajak kini yang dihasilkan dari perhitungan tarif pajak menurut Undang-Undang yang berlaku.

Pendekatan analisa strategi tarif pajak dilihat dari perspektif perencanaan pajak. Pendekatan ini dilakukan dengan 2 tahap, tahap pertama yaitu mendefinisikan langkahlangkah perencanaan pajak yang telah dilakukan perusahaan, misalnya pembayaran bunga, royalty, synthetic deductions, transfer pricing dan management fee. Tahap ke dua adalah membentuk laporan laba (rugi) yang dihasilkan dari masing-masing strategi yang dilakukan.Net benefit dari strategi-strategi tersebut dikalikan dengan tarif pajak yang berlaku, lalu dibagi dengan laba sebelum pajak, maka diperolehlah tarif pajak efektif.

Studi sebelumnya mengenai tarif pajak efektif telah menguji:

a. Tarif pajak efektif diberbagai jenis industri

b. Netralitas Sistem pajak perusahaan dalam hubungannya dengan ukuran perusahaan.

Biasanya, Jenis industri dan ukuran besaran perusahaan disesuaikan dengan pengaruh yang timbul dari karakteristik lainnya dari perusahaan, seperti Leverage (Total debt / Total Asset), Capital Intensity (Net PPE / Total Aset), kinerja perusahaan (ROAReturn on asset). Peneliti yang menguji pengaruh dari jenis industri terhadap tarif pajak efektif adalah Harberger,1959 ; Rosenberg, 1969 ; Siegfried, 1974. Mereka semua berubah haluaan karena pada tahuntahun tersebut perhatian lebih tertuju pada ukuran besaran perusahaan (Kern dan Morris, 1992 ; Kim dan Limpaphayom, 1998 ; McIntyre dan Nguyen, 2000; Porcano, 1986 ; Salamon dan Siegfried, 1977 ; Wilkie dan Limberg, 1990 ; Zimmerman, 1983).

Setelah Indonesia mengalami kemerdekaan di tahun 1945, ternyata ketidakstabilan politik yang masih terus berlanjut membuat perekonomian Indonesia memburuk, bahkan sejak tahun 1950, produksi domestik dan sektor investasi mengalami stagnasi, real income per capita di tahun 1966 dibawah real income per capita di tahun 1938. Karena hal ini pemerintah orde lama memutuskan 3 langkah terobosan, yaitu : stabilisasi, rehabilitasi, rekonstruksi ekonomi, semuanya ini dituangkan dalam konsep Repelita (Rencana Pembangunan Lima Tahun), Repelita ini membuat reformasi di bidang ekonomi, contohnya : liberalisasi di bidang investasi, capital balance. Ketika era pemerintahan orde baru sektor industri-lah yang menjadi fokus utama perekonomian.Dimasa orde baru ini pemerintah menerapkan strategi untuk membangun industri dalam negeri menggantikan impor, terutama membangun industri yang banyak menyerap tenaga kerja seperti tekstil, sepatu, perkayuan, makanan, otomotif.

Setelah mengalami resesi di tahun 1998, di tahun 1999 situasi ekonomi mulai masuk pemulihan dan hasil nya dibeberapa tahun belakangan ini, contohnya di tahun 2005 pertumbuhan ekonomi mencapai 5.5\%, angka yang menunjukkan kestabilitan makroekonomi.

Perubahan kebijakan pajak industri baru-baru ini (tahun $2009 \mathrm{~s} / \mathrm{d} 2010$ ) antara lain :

a. Pajak penghasilan atas badan usaha mengalami penurunan dari $30 \% \rightarrow 28 \%$ (ditahun 2009) dan 25\% untuk tahun 2010

b. Pajak atas penghasilan perorangan turun dari $35 \% \rightarrow 30 \%$

c. Batas penghasilan tidak kena pajak naik dari 2.880.000,- menjadi 15.840.000,-

d. Pajak pertambahan nilai atas ekspor jasa adalah $0 \%$ 
e. Kewajiban membayar pajak ditunda ketika Wajib Pajak masih dalam pemeriksaan

f. Insentif pajak berupa "tax holiday" bagi investasi baru yang berada pada sektor industri tertentu. Contohnya : industri dasar metal, industry pupuk dan kimia, industry mesin, industry komponen telekomuniaksi ( Government Regulation No. 94/2010)

g. Pedoman atas "transfer pricing" untuk melakukan transaksi dengan pihak-pihak terkait

Strategi jangka pendek 2010-2014, departemen perindustrian memiliki kebijakan industri dengan fokus kepada 6 area industry, yakni : industri padat karya (tekstil, sepatu, furniture), industri khusus (gula, pupuk, petrokimia), high growth industry (otomotif, elektronik), natural resources based industry (makanan, minyak sawit, karet, baja), capital intensive industry dan sme industry (keramik, kerajinan tangan, batu $2 x$ perhiasan).

\section{Sistem perpajakan}

Pajak penghasilan di Indonesia mengacu pada UU pajak penghasilan no 36 tahun 2008.Semua ketentuan perpajakan atas penghasilan yang diperoleh mengacu pada Undang-undang ini, baik untuk perorangan maupun badan. Seluruh perusahaan di Indonesia memiliki tarif pajak yang sama, yaitu 25\%.Tarif ini telah mengalami penurunan dari sebelumnya $30 \% \rightarrow 28 \%$ (tahun 2009) $\rightarrow$ lalu 25\% (tahun 2010).Untuk perusahaan dengan omset tertentu mendapat keringanan atas tarif pajaknya (Pasal $31 \mathrm{E}$, UU 36 tahun 2008). Kerugian dapat dibawa sampai 5 tahun ke depan (dapat dikompensasi ke pajak terutang ataslaporan keuangan sampai dengan 5 tahun ke depan). Penyusutan yang diperbolehkan di perpajakan Indonesia adalah metode garis lurus dan saldo menurun.

Dengan pemahaman yang telah dipaparkan diatas maka pertanyaan penelitiannya adalah :

1. Apakah profitabilitas mempengaruhi besaran tariff pajak efektif?
2. Apakah tingkat leverage mempengaruhi besaran tariff pajak efektif?

3. Apakah tingkat likuiditas mempengaruhi besaran tariff pajak efektif?

4. Apakah InvestorIndicators mempengaruhi besaran tariff pajak efektif?

5. Apakah cashflowindicators mempengaruhi besaran tariff pajak efektif?

\section{METODE PENELITIAN}

Data yang digunakan merupakan data laporan keuangan perusahaan yang telah diaudit dan yang listed di Bursa Efek Indonesia (BEI). Rentang waktu yang diambil adalah tahun 2016.Kemudian data laporan keuangan tersebut diklasifikasikan ke berbagai jenis industri yang menjadi bisnis inti dari perusahaan tersebut.

Ada beberapa hal yang perlu diperhatikan untuk perusahaan yang termasuk ke dalam kategori dibawah ini harus dikeluarkan dari data, yaitu :

- Perusahaan yang memiliki arus kas negatif atau rugi bersih aktivitas operasional, dan rugi bersih yang diakumulasikan ke tahun selanjutnya dikeluarkan dari data (Kim dan Limpapahayom, 1998 ; Wilkie dan Limberg, 1990)

- Perusahaan yang tarif pajak efektifnya $>1$ (lebih besar dari satu) dikeluarkan dari data (Gupta dan Newberry, 1997 ; Kim dan Limpapahayom, 1998 ; Singh, wilder dan chan 1987 ; Stickney dan McGee, 1982 ; Zimmerman, 1983). Tarif pajak efektif dari sebuah perusahaan dapat memiliki angka lebih besar dari satu, salah satu alasannya adalah proses konsolidasi antar grup perusahaan, anak perusahaan dengan net operating profit dan net operating loss.

- Perusahaan dengan tarif pajak efektif yang bernilai negatif juga dikeluarkan dari data (misalnya : perusahaan yang melaporkan kerugian, atau melakukan restitusi pajak)Penelitian ini mengikuti Wilkie (1988) dengan cara mengeluarkan 
perusahaan dengan tarif efektif pajak yang negative.

\section{Model}

$\mathbf{E T R}=\mathbf{a}+\mathbf{b 1}$ (profitabilitas) $+\mathbf{b 2}$ (Likuiditas) + b3 (Leverage) + b4(Investment Indicators) + b5 (cash flow Indicators)

\section{Definisi Operasional Variable}

Pengukuran tarif pajak efektif $($ ETR $=$ effective tax Rate) dilakukan, sesuai dengan penelitian Porcano (1986) yaitu :

ETR $=($ Tax expenses - deferred tax expenses) / Profit before interest and tax

Sedangkan variabel dependen yang digunakan adalah:

- Profitabilitas: ROA (return on Asset): Menurut Josua Kenon (2013), rasio ini menggambarkan efektifitas dari perusahaan, bagaimana setiap rupiah asset dapat menghasilkan laba yang dibutuhkan perusahaan. Secara teori, ((Singh, wilder dan chan 1987 ; Stickney dan McGee, 1982 ; Zimmerman, 1983) semakin tinggi profitabilitas, maka akan semakin tinggi pembayaran pajak. Namun hasil ini tidak sesuai dengan penelitian Kim dan Limpapahayom (1998) yang menyatakan tidak ada hubungan antara profitabilitas dan ETR.

- Leverage :Total Debt / Total Asset: Rasio ini ingin melihat bagaimana asset didanai oleh perusahaan. Namun demikian bunga hutang adalah biaya yang dapat mengurangi jumlah pajak.

- Likuiditas: Current Ratio ( Current Asset/Current Liability)" Rasio ini ingin melihat bagaimana kemampuan perusahaan dalam membayar hutang jangka pendeknya dari harta lancarnya. Semakin tinggi current ratio, perusahaan semakin likuid. Namun demikian karena kurangnya efektifitas asset, sehingga banyak asset yang harusnya menghasilkan laba tidak digunakan, mengakibatkan profitabilitas menurun. Hal ini dapat menjadi salah satu cara mengurangi pajak yang dibayar.

- Investment Indicators: Price to Book Ratio: rasio ini ingin melihat bagaimana pemegang saham memiliki harapan terhadap perusahaan. Semakin tinggi nilai PBR perusahaan, maka semakin tinggi harapan perusahaan. Penelitian ini ingin melihat bagaimana dampak harapan investor terhadap strategi pajak yang mungkin diterapkan oleh perusahaan.

- Cash Flow Indicators: Operating cash flow / Sales ratio. Rasio ini ingin melihat bagaimana sales dapat menjadi uang kas sehingga dapat dengan cepat mengembangkan perusahaan ataupun meningkatkan penjualan. Semakin tinggi cash flow indicators ini, maka beban pajak yang dibayarkan juga semakin besar.

\section{Metode Analisis Data}

Uji hipotesis yang dilakukan antara variabel independen dengan variabel dependen.Dalam penelitian ini digunakan metode analisis berganda, karena didasarkan pada tujuan penelitian yang ingin menguji pengaruh dari variabel-variabel bebas.Kemudian dilakukan beberapa uji kualitas data sebagai persyaratan analisis berganda.

\section{ANALISIS}

\section{Gambaran Umum Objek Penelitian}

Terdapat 474 perusahaan yang terdaftar di Bursa Efek Indonesia. Dari 474 data tersebut, terdapat 79 perusahaan ada dalam industri keuangan, 3 perusahaan mengalami kebangkrutan, 2 perusahaan delisting, 15 perusahaan listing di tahun 2013 dan 1 perusahaan di suspend sehingga tidak dapat digunakan dalam penelitian ini. Sehingga digunakan 374 data, yang dapat digunakan dalam penelitian ini. Setelah dilakukan Outlier analisa, digunakan 347 perusahaan yang benar-benar digunakan untuk melakukan analisa penelitian.

\section{Hasil}

Hasil analisis multiple regression yang meliputi R-square, F-value, koefisien parameter, dan t-value dari parameter yang ada dapat dilihat dari table 1 . 
Tabel 1

Hasil regresi untuk model yang diuji

\begin{tabular}{lcc}
\hline \multicolumn{1}{c}{ Variable } & Beta & t-value \\
\hline Constant & 0,142 & 10,313 \\
Profitabilitas & 0,259 & $3,115^{* * *}$ \\
\hline Leverage & $-0,002$ & $-2,887^{* * *}$ \\
\hline Likuiditas & 0,001 & $2,723^{* * *}$ \\
\hline Price to book ratio & $8 \mathrm{E}^{-6}$ & 0,098 \\
Cash flow indicators & 0,005 & 0,142 \\
\hline R-square & 0,046 & \\
Adj R-square & 0,033 & \\
Durbin-Watson & 2,150 & \\
F-test & 3,419 & \\
\hline P-value & 0.005 & \\
\hline Kolmogorof-Smirnof & 2,000 & \\
\hline
\end{tabular}

*** signifikan pada level $1 \%$

** signifikan pada level $5 \%$

*signifikan pada level $10 \%$

Dependent variables: ETR

Dari hasil analisa regresi diketahui bahwa faktor yang mempengaruhi tingkat ETR di Indonesia secara positif adalah tingkat profitabilitas dan tingkat likuiditas, sedangkan tingkat leverage mempengaruhi ETR secara negatif. Pada price to book ratio dan cash flow indicator tidak ada pengaruh dalam ETR.

\section{SIMPULAN}

Dari hasil penelitian dapat disimpulkan bahwa profitabilitas berpengaruh besar pada ETR. Hal ini sejalan dengan penelitian Diaz, Rodriguez dan Arias (2011), yang melakukan penelitian di perbankan spanyol, karena memang pajak terbesar yang dibayarkan adalah pajak atas laba. Secara umum pajak tidak semata-mata bisa diotak atik dengan

perencanaan pajak biasa ataupun melalui pembayarn pajak lain yang tidak berhubungan dengan laba. Demikian juga, ETR dipengaruhi oleh tingkat hutang dan tingkat likuiditas. Hal ini sejalan dengan penelitian Wang, Cambell dan Johnson (2014); Markle dan Shackelford (2011) yang membandingkan leverage dengan tingkat pembayaran pajak dari beberapa negara. Perusahaan-perusahaan di Indonesia menggunakan tax shield (Modigliani dan Miller, 1958) secara efektif. Hal ini dapat dilihat bahwa semakin banyak hutang yang dipunyai, semakin banyak pula laba yang dihasilkan dan pada akhirnya harus membayar pajak lebih besar. Sedangkan untuk mendapatkan pinjaman yang cukup, maka dalam laporan keuangan harus bisa meyakinkan debitor bahwa perusahaan akan membayar hutang 
tersebut tepat waktu. Untuk itu tingkat likuiditas harus meyakinkan.

Penelitian ini menyimpulkan bahwa faktor pemegang saham dan cash flow tidak mempengaruhi pembayaran pajak. Penelitian ini bertentangan dengan penelitian Wang (2015). Walau pajak menggunakan cash basis dalam perhitungannya, namun faktor cash flow terutama yang berasal dari kegiatan operasional tidak berhubungan dengan pembayaran pajak. Penggunaan kas melalui investasi jangka panjang, entah dalam bentuk aset tetap atau aset lainnya dan sumber pendanaan yang banyak melalui hutang jangka panjang membuat hasih penelitian ini menjadi tidak berpengaruh dengan pembayaran pajak. Demikian juga dengan pemegang saham. Managemen tidak memperhatikan faktor pemegang saham dalam strategi pajak mereka.

\section{Saran}

Untuk penelitian selanjutnya, mungkin lebih difokuskan pada strategi perusahaan dalam mengurangi pembayaran pajak, seperti faktor managemen laba atau faktor pembebanan biaya jangka panjang dan riset dalam peningkatan biaya. Sehingga dapat lebih jelas melihat motif manajemen dalam strategi pembayaran pajak.

\section{DAFTAR PUSTAKA}

Arryanto Sagala (Deputy Minister for the Assessment of Industrial Policy, Climate, and Quality Indonesia Industrial Policy).(2011) Indonesia Industrial Policy. Ministry of Industry

Chek Derashid a, Hao Zhang b,* (2003). Effective tax rates and the "industrial policy" hypothesis: evidence from Malaysia. Journal of International Accounting, Auditing \& Taxation 12 (2003) 45-62.

Dennis Botman, Alexander Klemm, and Reza Baqir. (2008). Investment Incentives and Effective Tax Rates in the Philippines: A Comparison With Neighboring Countries. IMF Working
Paper Fiscal Affairs Department and Asia and Pacific Department

Díaz, A. R. F., Rodríguez, E. F., \& Arias, A. M. (2011). Factores condicionantes de la presión fiscal de las entidades de crédito españolas, $i$ existen diferencias entre bancos y cajas de ahorros?. Spanish Journal of Finance and Accounting/Revista Española de Financiación y Contabilidad, 40(151), 491-516.

Ernst \& Young (2011). 2011 Asia Pacific tax policy outlook

KPMG's Corporate Tax Rate Survey 2006

Markle, K. S., \& Shackelford, D. A. (2011). Cross-country comparisons of the effects of leverage, intangible assets, and tax havens on corporate income taxes. Tax $L$. Rev., 65, 415.

McIntyre, R. S. \& Nguyen, T. D. C. (2000).Corporate income taxes in the 1990s. Washington, DC: Institute on

Modigliani, F., \& Miller, M. H. (1958). The cost of capital, corporation finance and the theory of investment. The American economic review, 48(3), 261-297.

Taxation and Economic Policy.

Omer, T. C., \& Molloy, K. H. (1991). Measurement of effective corporate tax rates using financial statementsinformation. The Journal of the American Taxation Association, 13, 57-72.

Roesler, Nishita; Getz, CJ. (2004). The Effective Tax Rate : Can it be Managed Without being analyzed? Journal of International Taxation 15. Â 10 (Oct 2004): $28-33+$

Seida, Jim A; Wempe, William F. (2004).Effective Tax Rate Changes and Earnings Stripping Following Corporate Inversion.National Tax Journal; Dec 2004; 57, 4; ProQuest pg. 805.

Shevlin, T. (1987). Taxes and off-balancesheet financing: Research and development limited partnership. The Accounting Review, 52, 480-509. 
Siegfried, J. J. (1974). Effective average U.S. corporation income tax rates. National Tax Journal, 27, 245-259.

Singh, D., Wilder, R. P., \& Chan, K. P. (1987).Tax rate in small and large firms. American Journal of Small Business, $22,41-52$.

Tulus Tambunan (2006). The Development of Industry and Industrialization Policy in Indonesia since The New Governance
Era to The Post Crisis Period. Kadin Indonesia-JETRO.November 2006.

Wang, L. (2015). Tax enforcement, corporate tax aggressiveness, and cash holdings. China Finance Review International, 5(4), 339-370.

Wang, Y., Campbell, M., \& Johnson, D. (2014). Determinants of Effective Tax Rate of China Publicly Listed Companies. International Management Review, 10(1), 10. 
